\title{
PUNCAK ANDALAS: \\ FUNCTIONAL REGIONS, TERRITORIAL COALITIONS, AND THE UNLIKELY STORY OF ONE WOULD-BE PROVINCE
}

\section{Keith Andrew Bettinger}

Since the fall of President Suharto and his authoritarian New Order government in 1998, Indonesia has experienced significant political and administrative transformation. Among the most conspicuous changes are those that have affected the geography of government. The decentralization reforms enacted in the wake of Suharto's forced resignation have not only altered the physical locus of a large spectrum of political and administrative powers, shifting them from Jakarta to outlying regions, but they have also allowed for the redrawing of Indonesia's political-administrative map. Redefining boundaries has been driven by a proliferation of administrative regions, a phenomenon known in Indonesia as pemekaran. ${ }^{2}$ By late 2013, 202 new districts (kabupaten) and administrative municipalities (kota) had been created, raising the

\footnotetext{
${ }^{1}$ I express my gratitude to two anonymous reviewers who provided comments and suggestions that greatly improved this essay. I also gratefully acknowledge the US-Indonesia Society and Mellon Foundation, without whose support this research would not have been possible. Lastly, I gratefully acknowledge comments and suggestions from Ehito Kimura, Krisnawati Suryanata, and Wendy Miles, all at the University of Hawai'i.

${ }^{2}$ Literally, "blossoming" or "flowering."
} 
national total to 500. In addition, eight new provinces were created, raising the total to thirty-four.

According to the decentralization laws governing pemekaran, ${ }^{3}$ there are several official justifications that allow for the creation of new regions. These include improving the delivery of public services, enhancing national security, accelerating regional economic development, and improving public participation in and the representativeness of government. ${ }^{4}$ Aside from these official justifications, though, most observers note that the proliferation of new regions is driven by district and provincial elites wishing to increase their rent-seeking opportunities. ${ }^{5} \mathrm{New}$ districts and provinces are heavily subsidized by funds from the central government, which are used to pay the salaries of new civil servants and to build the physical infrastructure for new administrative units. This creates ample opportunities for self-enrichment by local elites who are able to gain control of the new region, since they are responsible not only for awarding lucrative construction contracts, but also for hiring civil servants, a power that can be used for both personal enrichment (bribes) and to reward political supporters. These patronage powers are key to developing regional "kingdoms of authority $^{\prime 6}$ in decentralizing Indonesia. Thus, there are clear incentives for the formation of new regions, and the benefits stemming from administrative proliferation draw together alliances of elite actors at various scales to form "territorial coalitions."

Despite the unprecedented degree of administrative proliferation in Indonesia, many proposed regions have failed to be established because they were unsuccessful in gaining either the approval of the Ministry of Home Affairs or the necessary support in the national parliament. Thus, in many cases, the presence of a territorial coalition by itself is not sufficient to ensure the success of the proposed region. There are numerous reasons why these proposals fail, but the geographic concept of spatial regions provides some insight into the difference between success and failure. Geographers describe three basic types of regions: formal, functional, and vernacular or perceptual. ${ }^{8}$ All of the provinces that have been created in post-authoritarian Indonesia seem to fit very clearly into either the functional or formal category, or both. In cases where there is not a clear functional identity or agreed upon formal extent, the likelihood that a proposal to establish a new region will succeed seems to be greatly diminished.

\footnotetext{
${ }^{3}$ Government Regulation 129/2000 on Requirements and Criteria for the Creation, Abolishing, or Combining of Regions. This was later replaced by Government Regulation 78/2007.

${ }^{4}$ See Andre Oosterman, Costs and Benefits of New Region Creation in Indonesia: Final Report (Jakarta: Decentralization Support Facility, 2007).

${ }^{5}$ See: Tommy Firman, "Decentralization and Local-Government Proliferation in Indonesia: Towards a Fragmentation of Regional Development," Review of Urban and Regional Development Studies 21,2/3 (2009): 143-57; Fitria Fitriani, Bert Hofman, and Kai Kaiser, "Unity in Diversity? The Creation of New Local Governments in a Decentralizing Indonesia," Bulletin of Indonesian Economic Studies 41,1 (2005): 57-79; and Ehito Kimura, "Proliferating Provinces: Territorial Politics in Post-Suharto Indonesia," South East Asia Research 18,3 (2010): 415-49.

${ }^{6}$ Firman, "Decentralization and Local-Government Proliferation," p. 151.

${ }^{7}$ Kimura, "Proliferating Provinces," p. 415.

${ }^{8}$ Formal regions are those that are united by some common unifying characteristic, such as nationality, climate, or vegetation. Functional regions are centered on some type of shared activity or node. Vernacular (or perceptual) regions are delineated by human attitudes towards places. A fuller explanation of each is presented later in this essay.
} 
Figure 1: West Central Sumatra Today

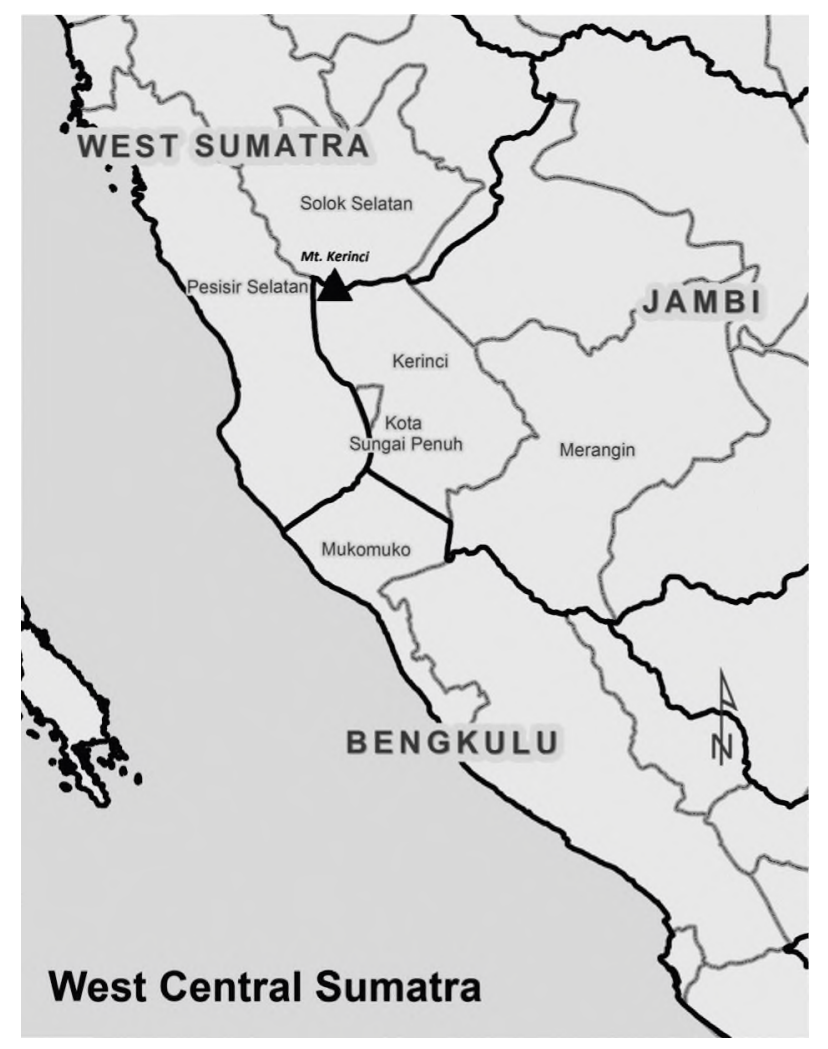

Regional elites vary in their capacity to overcome the obstacles that inhibit the formation of new regions. In some instances, districts and provinces have emerged fairly easily, while in other cases local elites face much higher hurdles and thus a more difficult ordeal to realize their aspirations of forming new administrative entities. This article is concerned with one such unlikely case: the prospective province of Puncak Andalas, ${ }^{9}$ on the island of Sumatra. As proposed, Puncak Andalas would be formed from parts of three existing provinces: Bengkulu, West Sumatra, and Jambi (see Figures 1 and 2). On the surface, the chances for this proposal's success seem quite remote, but a group of regional elites from peripheral corners of these existing provinces is convinced that the new province will eventually be created. This does not mean that they do not understand the challenges involved, though. There is no compelling regional identity that forms the basis of a formal or functional region in this case. There is no geographically discrete ethnic group that is marginalized by the current administrative configuration. And there is no historical justification, such as a prior identity, delineated, for example, by the traditional boundaries of a precolonial sultanate. Furthermore, the creation of this new province would require the establishment of at least two new districts as well as new road connections between the principal towns. In order to overcome these formidable hurdles, these local elites have

9 "Andalas" was a name used by Muslim travelers to refer to the island of Sumatra in the thirteenth century, and "puncak" means "peak" or "top." The name is a reference to Mount Kerinci, the highest active volcano in Indonesia (3,805 meters). 
embraced an incremental strategy whereby smaller, more attainable goals are targeted, including the development of transportation links and the establishment of new subdistricts. This incremental strategy broadens the base of support for each intervening goal while gradually establishing the basis of a functional region, thereby increasing the possibilities of Puncak Andalas eventually being approved as a new province. Moreover, this gradual, incremental strategy enables peripheral regional elites to proceed without the active cooperation of existing provincial elites. In this way, it is a sort of "backdoor" strategy for pursuing a new province. This essay examines in detail this incremental strategy and how it is currently being implemented. This account of the effort to form Puncak Andalas province is based on data collected from interviews with village, district, and provincial government officials, representatives from nongovernment organizations, and other societal figures, as well as media accounts gathered over the course of one year of field research in central Sumatra. ${ }^{10}$

The story of Puncak Andalas is a curious one for a number of reasons. First, it demonstrates how relatively weak local elites are able to manipulate a system that creates significant barriers for the creation of new provinces. This essay demonstrates how small, mundane initiatives orchestrated by local elites to improve their rentseeking opportunities create the foundation and momentum for more ambitious moves in the future. Second, the fact that Puncak Andalas would be carved from three existing provinces makes this case so exceptional that it is important to understand just how local elites would pursue its realization. ${ }^{11}$ An understanding of the incremental strategy described in this essay is a unique contribution to our knowledge of localnational interactions in decentralized Indonesia, and it provides insight as to how decentralization regulations are understood and enacted in practice. Moreover, the case of Puncak Andalas helps us to explore both the varied and contested notions of regions and the politics of decentralization in contemporary Indonesia. Lastly, this case shows that while the local elites pushing for the formation of Puncak Andalas province stand to benefit greatly, the residents of the largely peripheral areas that would constitute the new province could very well experience further marginalization and a deterioration of quality in terms of representation and actually receiving government services.

\section{Puncak Andalas Province: Geography and Supporters}

Since Puncak Andalas province would be created from pieces of three existing provinces, it would require a significant redrawing of the administrative map of western and central Sumatra, including the establishment of several new districts. From Bengkulu, the recently created (2003) district of Mukomuko would be added. West Sumatra would contribute the entire district of Solok Selatan, and Jambi province would yield Kerinci district and the administrative municipality Sungai Penuh, which

\footnotetext{
${ }^{10}$ August 2011-August 2012.

${ }^{11}$ Of the eight new provinces that have been formed since the fall of Suharto, all of them have been split from a single mother province. Moreover, of the eleven potential provinces envisioned in the Ministry of Home Affairs' Grand Design for Regional Arrangement 2010-2025 (Desain Besar Penataan Daerah di Indonesia Tahun 2010 2025), all would be formed from a single contributing province. See also Ridwan Max Sijabat, "How Many Provinces Does Indonesia Need?" Jakarta Post, April 20, 2012, p. 10.
} 
would become the new province's capital. Additional areas would be split from other existing districts and grafted on to Puncak Andalas as new districts as well. Currently, the Ministry of Home Affairs is considering a proposal to split Pesisir Selatan district in West Sumatra province, creating a new district called Ranah Indojati. Ranah Indojati would then become a part of Puncak Andalas. Jambi would also contribute a remote corner of Merangin district, which would be split off to form the new district of Jangkat. In addition, Kerinci district would be split into two new districts, Kerinci Hilir and Kerinci Hulu. These district splits would not only enable the new province to meet the legal minimum requirement of five districts necessary for the creation of a new province, but they would also create "kingdoms of authority" 12 for supporters. However, this project of administrative remapping is a daunting task requiring the cooperation of a range of actors in different provinces and at different levels of government.

The elites supporting the formation of Puncak Andalas can thus be thought of as a "territorial coalition," ${ }^{13}$ or an ad-hoc alliance of influential actors who find common cause in lobbying for a new province. Kimura describes three basic orientations for territorial coalitions: those that are dominated by national-scale actors, as in the case of West Papua; those that are dominated by local and regional interests, as was the case of Gorontalo province; and combinations of local and national interests, neither of which alone is powerful or influential enough to push successfully for a new province, but together are able to wield significant influence, as in the case of Riau Islands province. Puncak Andalas's supporters constitute a loose group that probably fits best into the second category, since they consist mainly of active and former district heads, members of district parliaments and their followers, and other key local and regional figures (tokoh masyarakat). What is most interesting about this coalition, though, is that it not only includes actors at different scales of government (e.g., local, regional, national), but it also brings together actors from multiple provinces. As noted earlier, all eight of the provinces that have been created since the fall of Suharto have been formed from a single "mother province" (propinsi induk). Therefore, if Puncak Andalas is eventually created, it will signify an unprecedented degree of interprovincial cooperation. Indeed, there have already been high-level negotiations and discussions among members of the legislatures of all of the existing districts that would become part of the new province. This degree of cooperation alone is noteworthy in this postauthoritarian era, when administrative Balkanization is frequently blamed for inefficient government. This remarkable case, then, demonstrates several hitherto unexplored aspects of administrative proliferation, as well as a potentially new pathway to provincial recognition. Though the supporters' group is said to count among its number several members of the Jambi provincial legislative assembly, as well as at least one member of the national parliament and a former cabinet minister, ${ }^{14}$ for the most part it consists of relatively marginal elites, hailing from somewhat

\footnotetext{
${ }^{12}$ Firman, "Decentralization and Local-Government Proliferation," p. 143.

${ }^{13}$ Kimura, "Proliferating Provinces," p. 416.

${ }^{14}$ It is widely acknowledged that Marzuki Usman, Minister for Tourism, Post, and Telecommunication under President Abdurrahman Wahid (1999-2001), is a primary backer of this proposal. Marzuki Usman has close family ties to Lempur, a complex of villages in Kerinci district that would figure prominently in any plan to form a new province.
} 
neglected corners of their respective provinces. This marginality is what brings them together, since for all of the elites in question the establishment of a new province would have several noteworthy benefits.

These benefits include greater access to state resources in the form of revenue from the central government. Support from Jakarta helps to prop up new provincial and district governments, and those infusions of revenue in many cases can prove to be quite lucrative to local elites. For example, Booth shows that central government funds in the form of General Allocations (Dana Alokasi Umum, DAU) and Special Allocations (Dana Alokasi Khusus, DAK) were higher per capital in five new provinces than in their mother provinces. ${ }^{15}$ The literature is rife with case studies describing how local elites are able to misappropriate central government funds. ${ }^{16}$ Suffice it to say here that more money from the central government generally means greater opportunities for rentseeking local elites. Related to this is the issue of "prestige" (prestasi). All of the informants I interviewed indicated that a new province would create greater opportunities for bureaucrats and elected officials alike to advance to more prestigious positions in the provincial government. Whether this is merely a euphemism for having greater access to the spoils of public office is difficult to say, but most informants who were in favor of the new province seemed to be sincere about their aspirations of wanting to take part in a higher level of government than what was currently available to them and in their conviction that the creation of a new province would draw more attention to the area at the national level and possibly even attract the world's gaze to central Sumatra.

Another factor that must be taken into consideration is access to natural resources. All of the districts that would become part of Puncak Andalas have significant proportions of their territory covered by Kerinci Seblat National Park (KSNP), a 1.3 million-hectare protected area (about 5,000 square miles) that stretches for 350 kilometers (217 miles) along the Bukit Barisan Mountains. ${ }^{17}$ The existence of the park unifies elites from different provinces, since under the terms of decentralization national parks are still under the control of the central government, and so district and provincial leaders are prohibited from developing and exploiting resources within parks. This rule is most adamantly challenged by district-level elites, who argue that the presence of the park leaves them at a competitive disadvantage compared to other districts that don't have protected areas. They assert that their potential to generate revenue from taxes and fees is severely compromised, which makes them more

\footnotetext{
${ }^{15}$ Anne Booth, "Splitting, Splitting, and Splitting Again: A Brief History of the Development of Regional Government in Indonesia," Bijdragen to de Taal-, Land-, en Volkenkunde 167,1 (2011): 31-59. See also Andrew McWilliam, "Marginal Governance in the Time of Pemekaran: Case Studies from Sulawesi and West Papua," Asian Journal of Social Science 39,2 (2011): 150-70, for a comprehensive description of the newly created Teluk Bintuni district in West Papua, which, during 2008, received approximately US\$100 million from the central government. The population of Teluk Bintuni was at the time approximately 60,000.

${ }^{16}$ See, for example, Vedi Hadiz, "Decentralization and Democracy in Indonesia: A Critique of NeoInstitutionalist Perspectives," Development and Change 35,4 (2004): 697-718; Fitriani, Hofman, and Kaiser, "Unity in Diversity?"; and Tommy Firman, "Territorial Splits (Pemekaran Daerah) in Decentralising Indonesia, 2000-2012: Local Development Drivers or Hindrance?" Space and Polity 17,2 (2013): 180-96.

${ }^{17}$ For example, approximately 51 percent of Kerinci district and 75 percent of Pesisir Selatan district are located within the park's boundaries.
} 
dependent on the provincial and central governments for funds. ${ }^{18}$ Thus, the presence of the park helps to explain both why local elites might want to break away from their current provinces (a new province would give them greater lobbying power and leverage in the national legislature against the Ministry of Forestry), and why the current provinces might let them go or even encourage them to bolt. In the latter case, the provincial governments may perceive these remote areas as drains on provincial resources, or areas that have to be subsidized. This dynamic is exacerbated by the fact that many of the districts in question (especially those in Jambi and Bengkulu) have noticeably lower levels of infrastructure development relative to other nearby districts. Thus, if these underdeveloped areas were to become part of a new province, the mother provinces would no longer be responsible for funding projects there. ${ }^{19}$ On the other hand, for the district elites who complain about the presence of the park, elevation to provincial status would give them a unified voice and more leverage against the Ministry of Forestry, which administers the park. It would also allow them to send legislators to the national parliament, who could exert pressure on the Ministry of Forestry to negotiate certain access rights to parts of the park. ${ }^{20}$ The Bukit Barisan mountains are widely thought to be rich in coal, gold, natural gas, and other resources, and so if local elites were successful in collaborating and renegotiating access rights, they would experience a significant windfall. Moreover, even if efforts to negotiate legal access were unsuccessful, establishment of a new province would also enable local elites to control various forms of informal and illegal access to the park. ${ }^{21}$

Lastly, regional elites might be persuaded to support a new province because it would offer them the possibility of moving up in the provincial pecking order. This would be true for leaders in both existing districts and those yet to be created. The leadership of all of the existing districts would benefit from their geographic and relational proximity to a new provincial capital, whereas for districts that have yet to be created, becoming part of a new province would increase elites' influence in provincial affairs compared to the clout they wielded in the old province. For example, if and when Ranah Indojati district is created, the district headman will be one of

\footnotetext{
${ }^{18}$ According to those who manage districts around the park, the park hinders their ability to benefit from locally generated revenue (pendapatan asli daerah, PAD). This is a particularly contentious issue in the era of regional autonomy because, while decentralization reforms have granted the districts more authority than they did under the Suharto regime, they also shoulder a greater responsibility for funding. Most DAU funds are used to pay salaries and to pay for day-to-day government expenses, and so any discretionary funds come from PAD. Making the situation even more contentious is the rebalancing of government revenues from natural resources that was implemented as part of decentralization (Law 25/1999), which gave districts a much greater share of fees from logging, mining, and other extractive activities carried out inside their boundaries. Consequently, districts turn to the primary sector to generate discretionary funds.

${ }^{19}$ A 2008 study conducted by the National Planning Agency (BAPPENAS) explicitly noted that parent regions often attempt to offload their poor residents to new autonomous regions; the study found that higher concentrations of poor people are found in new regions.

${ }^{20}$ This would certainly not be unprecedented. Zaini Abdullah, elected governor of Aceh province in 2012, has formally proposed to the Ministry of Forestry that some protection forests in the province be rezoned as production forests, which would open the door for oil palm extensification, logging, and mining. See Hayat Indriyatno, "Aceh Governor Wants to Allow More Logging in Protected Forests," Jakarta Globe, February 2, 2013, p. 13.

${ }^{21}$ Several scholars have asserted that potential access to natural resources has been a driver of province and district creation. See, for instance, Booth, "Splitting, Splitting, and Splitting Again" and Firman, "Decentralization and Local-Government Proliferation in Indonesia."
} 
twenty district heads in West Sumatra province, all presumably competing for influence with the governor, all attempting to foster coalitions at the national level. The new headman of Ranah Indojati in this case would likely be disadvantaged both by sheer numbers and the fact that he would be competing against existing networks of regional elites. However, if Ranah Indojati became part of Puncak Andalas, the headman would be one of only seven district leaders, and would in that case have much more influence in provincial affairs as well as access to national parliamentarians, and might even have a greater opportunity to one day become governor himself.

Another interesting characteristic of the Puncak Andalas coalition is that it illustrates Ehito Kimura's point that sometimes difference can lead to territorial coalitions. ${ }^{22}$ As mentioned in the previous section, the existing district of Kerinci would be split into two districts, namely Kerinci Hulu and Kerinci Hilir, according to this proposal. The Kerinci region historically has been known as an area riven by intervillage tensions and feuds. These upstream-downstream rivalries are a prominent feature of district politics to this day, and they have helped to fuel calls for the district to be split now that Sungai Penuh has become an independent municipality. Approval of the new province brings various subdistrict and village-level elites of the fractious district together because the formation of Puncak Andalas would facilitate the district split. Moreover, support for the new province crosses all party lines. Although the previously described creation of Ranah Indojati has been facilitated by party connections (discussed below), party affiliation doesn't seem to play much of a role in determining the membership of the territorial coalition supporting the new province, a situation that contrasts with Kimura's assertion that party affiliation is sometimes a unifying factor for coalitions. ${ }^{23}$ Instead, regional elites in these districts usually form ad-hoc associations with political parties for the purpose of contesting district elections.

\section{The Importance of Regional Identity}

Since 1998, numerous new provinces have been proposed, but only eight have been established. Moreover, the rate of province formation has slowed significantly as the central government has struggled to regain control of administrative proliferation. ${ }^{24}$ Still, campaigns to create new provinces are frequently covered in national and regional media outlets, indicating that territorial coalitions still have ambitions to create new regions. What makes the difference between a successful and failed campaign to form a new province? Geography offers a simple yet useful conceptualization of regions that helps to explain the political aspects of provincial formation in Indonesia and casts some light on the Puncak Andalas proposal's potential for success. As stated earlier, most introductory human geography textbooks

\footnotetext{
${ }^{22}$ Kimura, "Proliferating Provinces."

${ }^{23}$ Ibid.

${ }^{24}$ President Susilo Bambang Yudhoyono instituted a moratorium on the creation of new regions after the death of North Sumatra legislative assembly speaker Abdul Aziz Angkat, in 2009. Angkat died during a violent demonstration in support of the creation of Tapanuli province, which was to be split off from North Sumatra. Though the moratorium was not legally binding for the national parliament, no new regions were created until late 2012.
} 
discuss three types of regions: formal, functional, and perceptual. ${ }^{25}$ Formal regions are those that are united by some common unifying characteristic, such as nationality, climate, or vegetation. Indonesia is a formal region, as are its provinces and districts. Functional regions, in contrast, are centered on some type of activity. Common examples include newspaper-delivery areas or the listening area of a radio station. For instance, the area serviced by public transport oplet minibuses in Padang would be a functional region, as would the broadcast territory of a local television station. Lastly, perceptual regions refer to human attitudes towards places. Perceptual regions (also sometimes referred to as "vernacular regions") are somewhat subjective, as their definitions and boundaries might vary from person to person. "Dixie" is a commonly cited example of a perceptual region in the United States.

\section{Table 1: Provinces Created since 1998}

$\begin{array}{lcl}\text { Province } & \text { Year Established } & \text { Mother Province } \\ \text { Bangka-Belitung } & 2000 & \text { South Sumatra } \\ \text { Banten } & 2000 & \text { West Java } \\ \text { Gorontalo } & 2000 & \text { North Sulawesi } \\ \text { North Maluku } & 1999 & \text { Maluku } \\ \text { North Kalimantan } & 2012 & \text { East Kalimantan } \\ \text { Riau Islands } & 2004 & \text { Riau } \\ \text { West Papua } & 2003 & \text { Papua } \\ \text { West Sulawesi } & 2004 & \text { South Sulawesi }\end{array}$

Table 1 lists the provinces that have been formed since the fall of Suharto. All of these can be classed as either formal or functional regions, or a combination of the two. Gorontalo province, for example, has a distinctive history and cultural tradition. ${ }^{26}$ It can thus can clearly be defined as a formal region, and, given the laws on regional autonomy, there was a strong case to be made for the formation of this province. ${ }^{27}$ Booth describes the formation of Banten province on Java, which was split off from West Java in $2000 .^{28}$ At that time, West Java was the largest province in Indonesia in terms of population, with a staggering population of forty million people. Many in the

\footnotetext{
${ }^{25}$ For example, see James Rubenstein, Contemporary Human Geography (New York, NY: Prentice Hall, 2010); and Alyson Greiner, Visualizing Human Geography (Hoboken, NJ: Wiley, 2011).

${ }^{26}$ Ehito Kimura, "Marginality and Opportunity in the Periphery: The Emergence of Gorontalo Province in North Sulawesi," Indonesia 84 (2007): 71-95.

${ }^{27}$ This is not to say that other factors did not come into play in each of these cases. For an excellent account of the political machinations behind the formation of Gorontalo, Kepulauan Riau, and West Papua provinces, see Ehito Kimura, Political Change and Territoriality in Indonesia: Provincial Proliferation (London: Routledge, 2012).

${ }^{28}$ Booth, "Splitting, Splitting, and Splitting Again," p. 42.
} 
government felt that such a large population made it impossible for the provincial government to provide public services fairly and efficiently. At the same time, the people of Banten had a distinct history and culture and were also geographically separate from the majority Sundanese, who are concentrated in the highlands around Bandung. Thus, in addition to arguments based on administrative efficiency, the people of Banten were successfully able to argue that they deserved to have their own province. Given these conditions, we can conclude that Banten is a formal region that also displays elements of a functional region. ${ }^{29}$

Other new provinces are more accurately described as functional regions. One example would be the Riau Islands (Kepulauan Riau), centered on the island of Batam. These islands have a long history of association with the Johor Sultanate, but more recently have been associated with Singapore and Peninsular Malaysia via the establishment of the SIJORI (Singapore-Johor-Riau) growth triangle. ${ }^{30}$ Thus, these islands form a functional region of export processing that takes advantage of its proximity to Malaysia and Singapore. The history of the Riau Islands suggests the area could be treated as a formal region as well. North Maluku and the Bangka-Belitung Islands both demonstrate characteristics of functional regions, as these provinces were created, in part, to cut down on administrative costs incurred by the long distances separating the residents of the region from the capital of their mother provinces. The new provincial capital serves as an economic and administrative hub that, theoretically, serves to make government more efficient and responsive to the needs of the people. Indonesia's newest province, North Kalimantan, formed in 2012, might appear at first to be something of an exception to the formal/functional region rule, given that it is among the least densely populated provinces in the country. However, the province was ostensibly created in response to concerns about the integrity of the border with Sarawak and Sabah in the wake of an International Court of Justice case that awarded the islands of Sidapan and Ligitan to Malaysia. ${ }^{31}$ One of the main reasons for forming the province was to speed development on the frontier to ensure the loyalty of people living near relatively richer Sabah and Sarawak. North Kalimantan can be viewed as a formal region in that it is defined as a strategically important focal point, a target of development. Thus, virtually all of the new provinces created in Indonesia since the fall of Suharto had clear identities or economic orientations (or both) prior to their formal establishment as provinces.

Failed campaigns to create provinces also provide some lessons as to the difficulty of these sorts of ventures, and show some of the common problems that can derail a campaign to form a new province. Dik Roth explains the saga of the failed effort to form the province of Luwu Raya on Sulawesi, a province that would have combined Tana Toraja and Luwu districts. ${ }^{32}$ These two areas have historical connections, but the

\footnotetext{
${ }^{29}$ It can be argued in many of these cases that the areas under discussion could be described as both functional and formal regions, and even in some instances as perceptual regions as well. In this discussion I am highlighting the characterization (formal, functional, or perceptual) that seems to figure most prominently in the creation of the new province.

${ }^{30}$ Kimura, Political Change and Territoriality in Indonesia.

${ }^{31}$ Bruce Gale, "New Indonesian Province Means New Set of Problems," Jakarta Globe, February 12, 2013, p. 8.

${ }^{32}$ Dik Roth, "Many Governors, No Province: The Struggle for a Province in the Luwu-Tana Toraja Area in South Sulawesi," in Renegotiating Boundaries: Local Politics in Post-Suharto Indonesia, ed. Henk Schulte-
} 
extent of the Greater Luwu region was opened up to reinterpretation after the departure of the Dutch. Throughout the course of the postcolonial era, various powerful interests have attempted, with varying degrees of success, to redefine the region in accordance with their political agendas. The result is that there is now no clear consensus among local and national elites on the extent and identity of Greater Luwu. One might make the argument that the historical formal region has gradually become a perceptual region, and thus the case for provincial formation is much less compelling. Disputes among regional elites concerning what areas would be included in the new province ultimately led to the failure of the attempt to establish Luwu Raya. $^{33}$

Another instructive case is that of Cirebon, a prospective province that would be split off from West Java. Calls for the formation of Cirebon province, which would be formed from four or five districts that are currently in the northwestern corner of West Java province, seem to have emerged after Banten province was formed from West Java. According to George Quinn, this split led to a movement to emphasize the identity of West Java as the Sundanese homeland. ${ }^{34}$ Elites in Cirebon began to argue that their people, who have an identity distinct from that of the Sundanese majority in West Java, were being marginalized by the provincial government in Bandung. Over the course of several years, regional elites held meetings to discuss calls for a new province, ${ }^{35}$ but a schism developed among the young movement's leadership over the details of implementation, which slowed the proposal's momentum. Though this campaign is ongoing and may eventually result in the formation of a new province, it illustrates the difficulties of forming new administrative units.

\section{Functional Regions as the Basis for Province Formation}

Puncak Andalas doesn't fit the bill as a functional, formal, or perceptual region. It is ethnically heterogeneous and lacks a marginalized cultural minority. There are no large religious minorities residing in its boundaries since practically everyone is Muslim, ${ }^{36}$ and there is no history of religious conflict or tension. There is no historical kingdom or distinct culture that unites the area. Most of the groups in the area have long and rich histories, but each group has a separate and distinct tradition. Thus, in the case of Puncak Andalas, a strategy relying on "identity politics," whereby religion

Norholt and Gerry van Klinken (Leiden: KITLV Press, 2007), pp. 121-50. Both Tana Toraja and Luwu districts have experienced at least one split since the reformasi movement began.

${ }^{33}$ It should be noted here that the campaign to establish Luwu Raya likely failed in part due to divisions within its supporting territorial coalition. Indeed, territorial coalitions and coherent regional identity should be considered as mutually constitutive.

${ }^{34}$ George Quinn, "Coming Apart and Staying Together at the Center: Debates over Provincial Status in Java and Madura," in Local Power and Politics in Indonesia: Decentralisation and Democratisation (Singapore: Institute of Southeast Asian Studies, 2003), pp. 164-78.

${ }^{35}$ See: Nana Rukmana, "Regency Legislatures to Prepare Formation of Cirebon Province," Jakarta Post, November 8, 2001, http:/ / www.thejakartapost.com/ news/2001/11/08/ regency-legislatures-prepareformation-cirebon-province.htm, accessed March 11, 2013; and Nana Rukmana, "Calls Mount for Cirebon Province," Jakarta Post, August 7, 2002, http:// www.thejakartapost.com/ news/2002/08/07/ calls-mountcirebon-province.html, accessed March 11, 2013.

${ }^{36}$ There are very small Christian minorities throughout the area. These include some ethnic Chinese, Batak, and Javanese migrants. 
or ethnicity may be used as fulcrums to achieve political ends, would most likely be a non-starter. ${ }^{37}$ Moreover, there are no real defined patterns of commerce centered on a hub that would define it as a functional region on the scale of a province. Rather, most of the commerce in the area ultimately passes though the port of Padang, but the distance from this region to Padang is widely held to be a burden on commerce. In addition, the proposed boundaries for Puncak Andalas do not encompass a particularly large area with a huge population, as in the case of West Java. The current population of the districts and subdistricts that would become Puncak Andalas is approximately 850,000. As noted earlier, the districts that would become Puncak Andalas would be drawn from three existing provinces (Bengkulu, West Sumatra, and Jambi) and represent the most far-flung parts of those provinces. Thus, unlike the cases involving the new provinces described above, there isn't a strong or particularly compelling preexisting case for creating this new province on the basis of any of the commonly used logics. In the present case, most arguments for the new province focus on the distance from the districts involved to their respective provincial capitals, as well as a general feeling, on the part of local residents and their leaders, that they have suffered from government neglect. For example, the head of the Kerinci district legislative assembly was quoted as saying publicly, "Jambi province must be split into two, that is, Jambi province and Puncak Andalas. This should have been done long ago, because the distance from the capital of Jambi to the districts and municipalities, especially Merangin, Kerinci, and Sungai Penuh, is very far." ${ }^{38}$ Elected officials and bureaucrats in remote areas frequently cite disparities between the provincial outlays received by their districts and funds received by areas closer to the provincial capital as evidence of neglect. They also argue that they are too far away from their provincial capitals to lobby effectively for their districts, and the leaderships of districts closer to Jambi City, Bengkulu City, and Padang have an unfair advantage, both in terms of formal and informal political processes. Unfortunately for the local elites, the distance argument is likely not enough by itself to compel national authorities to approve the formation of a new province. ${ }^{39}$ Still, that argument and the feelings of being neglected seem to have the effect of encouraging far-flung district elites to cleave to one another, in effect creating what might be considered a new type of region, whereby similar circumstances are conducive to the emergence of personal ties and informal connection among political and business leaders of different districts and provinces. This could be

\footnotetext{
${ }^{37}$ Jacqueline Vel, "Campaigning for a New District in West Sumba," in Renegotiating Boundaries, pp. 91-120. Vel examines efforts to form new districts in the island of Sumba in Eastern Indonesia. Sumba, she argues, is relatively homogenous religiously and ethnically and thus has some parallels with the current situation.

38 "Provinsi Jambi memang harus dimekar jadi dua, yaitu Provinsi Jambi dan Provinsi Puncak Andalas. Hal itu harusnya terjadi sejak dulu, karena jarak ibukota Provinsi Jambi dengan kabupaten dan kota, terutama Merangin, Kerinci, dan Sungai Penuh sangat jauh," quoted in "Isu Pembentukan 'Provinsi Andalas' Kembali Mencuat," Jambi Daily, October 6, 2012, http: / / jambidaily.com/ v3/ peristiwa/416-isupembentukan-provinsi-puncak-andalas-kembali-mencuat, accessed February 28, 2013.

${ }^{39}$ The distance argument is commonly used in advocating for new regions. While it doesn't seem to be sufficient in and of itself to merit a new province, it has been an effective argument for new districts. This argument was used to justify the creation of Solok Selatan district in 2003 and is currently being used by advocates of splits in both Kerinci and Pesisir Selatan districts.
} 
termed a "network" or "affinity" region, which emerges by default when connections to other regions are weak. ${ }^{40}$

Figure 2: Proposed Puncak Andalas Province

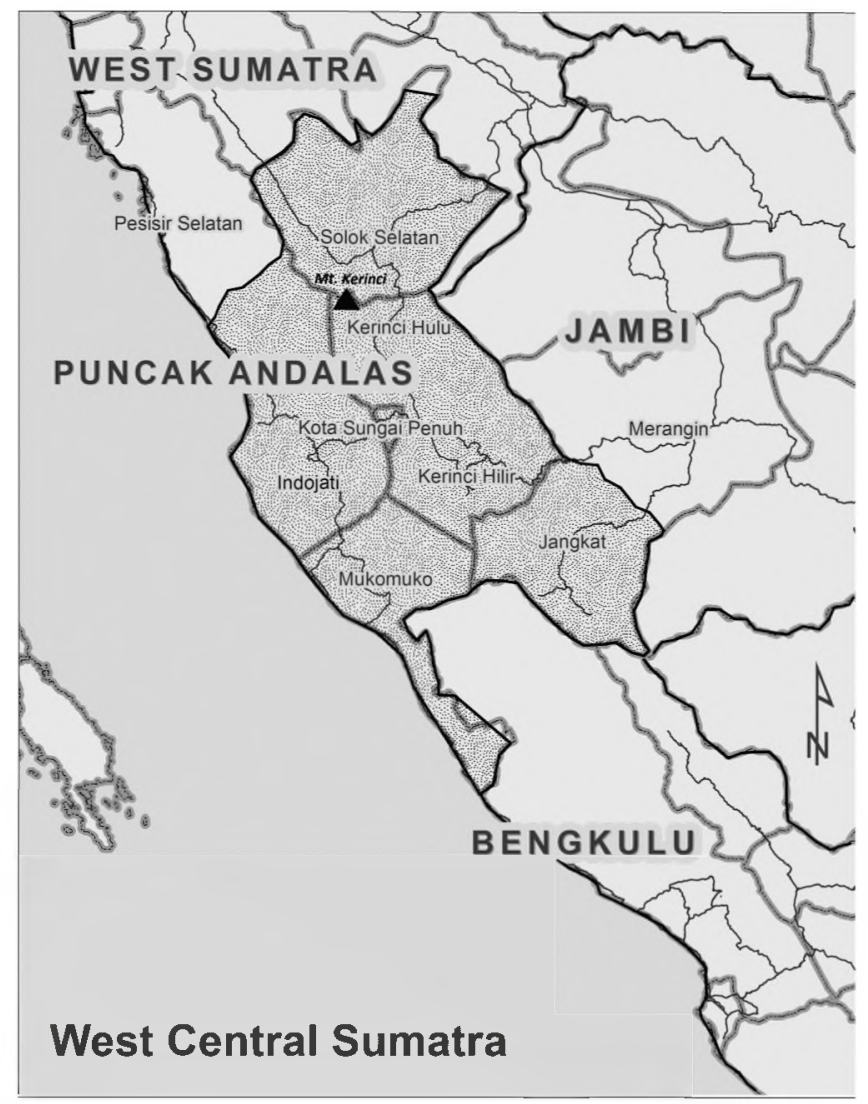

For this reason, local elites have to create some sort of regional identity if they ever want to see their dream of a new province realized. ${ }^{41}$ The most sensible way to do this would be to foster an economy-based functional region centered on a hub, which would, according to the plan, be Sungai Penuh, which is in the approximate center of the would-be province. However, so far there isn't much active support among provincial or national elites for forming a new province, as it is still widely perceived to be a vision impossible to realize. Thus, for devoted supporters of the new province,

\footnotetext{
${ }^{40} \mathrm{My}$ intention here is not to distract the reader by proposing a new class of regions, but rather to make a point. It might be observed that an "affinity region," so-called, is similar to a functional region, and probably should be considered a very specific instance of a functional region. From my interviews and fieldwork, I gathered a great deal of secondhand, and undocumented, information about growing connections among elites in the area that would become Puncak Andalas. For example, land in one district was gifted to the district head of a neighboring district; and contractors connected to the district head of one district were given preferential treatment in tendering for projects in a neighboring district.

41 "Provinsi Puncak Andalas Diwacanakan Kerinci Siap Pisah Dari Jambi," Radar Kerinci, August 5, 2010, p. 1.
} 
the best approach is an incremental one. ${ }^{42}$ In other words, they are approaching the ultimate objective as a series of smaller goals. This makes it easier to mobilize active support for each incremental task, and the administrative (and financial) barriers for these goals are much easier to overcome. These intervening goals are described in the following sections.

Step One: Establish Subdistricts. Subdistricts (kecamatan) are relatively small and fairly easy to create. All of the requirements for new subdistricts, except for one, can be fulfilled within the district itself, and, given the massive proliferation of subdistricts, the last requirement-approval of the provincial governor-seems to be a minor obstacle, at most. ${ }^{43}$ It is relatively easy to win widespread support for a new subdistrict since its establishment increases recognition for the people in the subdistrict. ${ }^{44}$ There are also always a few new administrative positions created, and government money flows to subdistricts, ${ }^{45}$ so most people are in favor of their formation. But new subdistricts have two other functions. First, the head of the subdistrict (camat) is the only official in the government hierarchy who is not elected ${ }^{46}$ instead, the camat is picked by the district head. Thus, camat positions can be used to reward loyal supporters and prepare them for positions as heads of district bureaus, and camat positions can also be used to create a powerful electoral machine at the subdistrict level that generates votes. ${ }^{47}$ Second, according to regulation $19 / 2008$, at least five subdistricts are required to create a new district (step two, discussed below).

${ }^{42}$ This statement is based on interviews with several of the prime movers behind the Puncak Andalas movement. One of the common threads that emerged from my discussions with these leaders is that they see the process of creating a new province as a long-term project; one mentioned the timeframe of twenty to twenty-five years.

${ }^{43}$ Government Regulation 19/2008 spells out the role of the subdistrict and its head within the context of Indonesia's administrative hierarchy. Requirements for forming new subdistricts include the following:

1. Agreement from all village representative councils involved,

2. Agreement from all village heads,

3. Inclusion of at least ten villages or wards (in urban areas the requirement is five),

4. Research conducted on the part of the district or administrative municipality showing that the proposed subdistrict (and mother subdistrict) meet a number of loosely defined technical requirements, and

5. A recommendation from the governor.

The Ministry of Home Affairs in 2012 issued a moratorium on subdistrict formation beginning August 1, 2012, and ending in 2014, to allow for preparations for the 2014 nationwide elections. However, the establishment of subdistricts that had already been approved would not be interrupted.

${ }^{44}$ The issue of increasing recognition was raised by interviewees from the village level all the way up to the provincial level.

${ }^{45}$ The amount of money available to subdistricts varies from place to place depending on the programs that have been implemented by the provincial and central governments, as well as any outside (multilateral, bilateral, or international NGO) involvement. In 2012, the governor of Jambi province announced grants of up to IDR one billion (slightly more than US\$100,000) per subdistrict.

${ }^{46}$ Heads of kelurahans, which are parallel with desas and are found in urban areas, are also appointed civil servants.

${ }^{47}$ Hans Antlov and Eko Sutoro, "Village and Subdistrict Functions in Decentralized Indonesia," paper presented at the Decentralization Support Facility's (DSF) closing workshop on "Alternative Visions for Decentralization in Indonesia," March 12-13, 2012), p. 5. The authors argue that "very few camats have a voice in district policy making: they are often either young (albeit sometimes upcoming) government officials or ineffective civil servants in need of a place to retire." In contrast, in central Sumatra, the position of camat is widely seen as a stepping-stone on the way to becoming the head of a district government office (kepala dinas). The maximum civil service rank for a camat is echelon IVb, which is one 
Subdistrict proliferation can be seen in the districts involved in the plan to create Puncak Andalas province. For example, Merangin district, which, according to the plan, would be split to form a new district (called Jangkat), increased from nine subdistricts in 2006 to twenty-four in 2012. Perhaps more importantly, the part of the district that would be ceded to form a new district now has five subdistricts (formerly there were three), which fulfills the key technical requirement for creating a new district. Likewise, Pesisir Selatan district, which also would be split into two districts (Pesisir Selatan and Ranah Indojati) to facilitate the formation of Puncak Andalas province, created three new subdistricts in 2012, increasing to six the number of subdistricts in the southernmost portion of the district, which would be split off to form a new district. Lastly, Kerinci district, which lost five subdistricts when Sungai Penuh was split off as an independent administrative municipality in 2008, created four new subdistricts in 2012, for a total of twelve. District officials in Kerinci openly admit that their goal is to create a new district; the head of the district assembly was quoted in a local newspaper as saying "if this subdistrict is made official, then Kerinci district will have four new districts, so that the road to dividing the district into two governments is more open." ${ }^{48}$ This means that Kerinci district now has enough subdistricts to be split into two districts. Conversely, in the two districts that would join Puncak Andalas province without district splits (Solok Selatan and Mukomuko), there have been no new subdistricts created in the past five years, which suggests the possibility that, in Kerinci and Merangin, subdistricts have been created proactively because the leaders involved are tentatively planning or hoping to split districts. ${ }^{49}$

Step Two: Establish New Districts. According to the aforementioned 2008 regulation, at least five districts and municipalities are required to form a new province. Thus, Puncak Andalas currently is one district short of the requisite number. Establishing new districts is significantly more difficult than creating subdistricts, in part because it requires either a special law to be passed by the national legislature or approval from a multi-ministerial committee headed by the Ministry of Home Affairs. ${ }^{311}$ However, in 1998, before the fall of President Suharto, there were 292 districts and administrative municipalities and currently there are five hundred, so there is an established pattern of new district formation in the post-Suharto era. This onslaught of administrative proliferation began in the year 2000 with the passage of Government Regulation $129 / 2000$, described above. A large number of these new districts have been created on Sumatra, and, in particular, in the area that would become Puncak Andalas province. Merangin (formerly part of Sarolangun-Bangko district ${ }^{51}$ ), Solok Selatan (split off from Solok district), Mukomuko (split off from Bengkulu Utara in 2003) and Sungai Penuh (split off from Kerinci district) are all relatively new administrative entities.

step below echelon IVc, the rank of district office heads. This means that camats conceivably can be promoted directly to become district office heads, whereas subheads (kepala bidang) cannot.

48 "Kalau kecamatan ini disahkan nanti, maka kabupaten Kerinci akan memiliki 4 kecamatan baru, sehingga arah menuju pemekaran kabupaten menjadi 2 pemerintahan semakin terbuka," quoted in "Kerinci Bisa Dimerkarkan Lagi," SIKE, December 9, 2011, p. 3.

49 This conclusion is supported by comments to this effect from numerous informants in the field.

${ }^{50}$ New district formation is governed by Government Regulation 78/ 2007 on Procedures for Forming, Dissolving, and Merging Regions.

${ }^{51}$ Sarolangun-Bangko was split in 1999 to form Sarolangun and Merangin districts. Merangin, which inherited the old district capital of Bangko, is technically the mother district. 
New subdistricts help make the case for the establishment of new districts, but popular support and elite coalitions are essential as well. In each of the cases of new district formation described above, coalitions of district, provincial, and national-level actors were instrumental in forming the new districts. In the first few years after the passage of law 129/2000, most new districts were approved, an indication that these coalitions were able to take advantage of a particular historical juncture to elevate their position and status. After law 129/2000 was revised in 2007, it has become more difficult to create new districts, but there are currently campaigns afoot in several stages of development to orchestrate district splits that would contribute to the creation of Puncak Andalas province. The most advanced of these movements is the one to create a new district, Ranah Indojati, from the southernmost portion of Pesisir Selatan district in West Sumatra province. The plan has already been approved by the district leadership and the provincial government and has been submitted to the Home Affairs Ministry along with supporting technical documentation. The new district has widespread support, especially from residents of the six subdistricts who claim that they have long been neglected by the district government in Painan, the district seat of Pesisir Selatan. Moreover, they say that the distance to Painan is a significant hardship for them and that it reduces the efficiency of government. If the geographic characteristics of nearby districts are any guide, Ranah Indojati stands a good chance of being approved; Pesisir Selatan is twice as large as most of the other districts in the neighborhood, and its population of approximately 450,000 is far larger than that of many other districts. In addition, local leaders feel that Minister of Home Affairs Gamawan Fauzi, himself a Minang, strongly supports the formation of the new district. ${ }^{52}$ Time is of the essence, though, since national elections will be held in 2014, and it is likely that Gamawan Fauzi's tenure as minister will come to an end with the election.

Efforts are also underway in Kerinci to split the district in two, but the earliest this could occur would be in 2015, since the Sungai Penuh-Kerinci split happened in 2008 and there is a seven-year waiting period for new splits. This split has widespread support throughout the usually fractious district. The most powerful members of the district assembly, as well as the current and former headmen, are very vocal in their support for the split, and they have had meetings to endorse the plan and coordinate their efforts. Members of the district assembly routinely make public statements in support of the split, framing the issue as an inevitable outcome of conditions in Kerinci. Moreover, there are powerful supporters in the Jambi provincial assembly, including

\footnotetext{
${ }^{52}$ Gamawan Fauzi was born in Solok, the mother district of Solok Selatan, one of the districts that would become part of Puncak Andalas. The fact that the proposal was channeled through the Ministry of Home Affairs is notable itself, since most proposals for new provinces and districts are channeled through the national parliament. It makes sense, then, that the minister would be instrumental in this move, but this connection is only part of an elite coalition supporting the Pesisir Selatan split. Gamawan Fauzi previously served as governor of West Sumatra province. After he supported the reelection bid of Democratic Party candidate Susilo Bambang Yudhoyono, he was appointed minister. The creation of the new district is also supported by the chairman of the Democratic Party for Pesisir Selatan, who currently serves in the West Sumatra provincial legislature. He is from Lunang Silaut, a town in the part of Pesisir Selatan that would become the new district, and hence would stand an excellent chance of being appointed and then elected district headman of the new district. Moreover, the current head of Pesisir Selatan district, though a member of the National Mandate Party (Partai Amanat Nasional, PAN), was elected in part due to support from the Democratic Party.
} 
the wife of the former district headman. ${ }^{53}$ According to local informants, the desire for this new district goes back to the 1970s, but, after reformasi laws were passed, the case for a district split was weak, as there was no clear consensus among the district elites regarding how the split would be effected. Thus, the creation of Sungai Penuh as an independent municipality was agreed upon as a kind of stopgap measure or compromise. Ironically, calls for an additional split have intensified since Sungai Penuh was split off, as tensions between residents of "upstream" Kerinci (Kerinci hulu) and "downstream" Kerinci (Kerinci hilir) have increased. One major cause of this renewed regionalism is that Bukit Tengah, a small village about forty-five minutes north of Sungai Penuh, was selected to be the new district capital in a process that was widely thought to be corrupt. ${ }^{54}$ Downstream Kerinci residents contend that the 2008 split has actually decreased the level of public-service benefits they receive, since they have to travel farther to reach the new district capital. (They say the trip is a hardship because it can no longer be made in one day and requires an overnight stay.) They also claim that upstream Kerinci residents are being disproportionately selected for jobs in the district government and that businessmen with ties to the current district headman are receiving the most lucrative district contracts. Cynical observers suggest that the selection of Bukit Tengah was all part of a plan to make the case for an additional split later, while more stoic residents dismiss the alleged corruption as being an inherent aspect of Indonesian politics. Whatever the explanation, though, the selection of Bukit Tengah as district seat and the perceived nepotistic politics of the current district head have fueled calls for a new district. ${ }^{55}$

Efforts to split Merangin into two districts (Merangin and Jangkat) are less advanced than in the other districts, but they are underway, and it is reasonable to expect that they will gain momentum in the near future, especially if the Pesisir Selatan and Kerinci splits are approved. As of this writing, in early 2014 the district government of Merangin has not formally begun the research required to examine the feasibility of the split, and the district leaders, though supportive of the plan, are less vocal about it than are leaders in other districts. However, there is a base of support for the creation of the new district, and the close ties between high level bureaucrats and elected officials in Merangin and Kerinci districts suggest that there is most likely coordination among them. ${ }^{56}$ As described above, the district government has created the necessary subdistricts to realize the split, and so it is likely only a matter of time before the movement gains momentum.

As mentioned above, new districts bring tremendous benefits for local elites, including the opportunity to select a new headman. New districts also receive an enormous amount of funds from the central government (at the expense of pre-existing

\footnotetext{
${ }^{53}$ This couple is also among the most outspoken supporters of Puncak Andalas province.

${ }^{54}$ Bukit Tengah is the hometown of the current headman of Kerinci district. Bukit Tengah was selected against the advice of an expert technical team from the Institute of Technology in Bandung, which recommended four prospective sites for the new district seat, each of which would be more centrally located than Bukit Tengah.

${ }^{55}$ For a full description of the Kerinci-Sungai Penuh split and the problems that have emerged from it, see Keith Bettinger, "The Secret Valley Divided: Administrative Proliferation in Kerinci Valley, Jambi Province, Sumatra, Indonesia," Journal of Rural Indonesia (Forthcoming 2014).

${ }^{56}$ Rakyat Merdeka, "Muko-muko Ajak Kerinci Bergabung," Rakyat Merdeka, March 18, 2007, p. 2.
} 
districts and provinces) in the form of general allocations, special allocations, and balancing funds. And in addition to the contracts associated with the construction of the new district seat, all of the newly created civil service positions provide ample opportunities for rent-seeking. ${ }^{5 /}$ For all of these reasons, new districts generally enjoy widespread support among local residents and their establishment is seen as a realistic and worthy goal. Forming a new district has even become a campaign promise for at least one candidate for district headman. ${ }^{58}$ Therefore, in and of themselves, district splits are a lucrative goal, but in this case-namely, the formation of Puncak Andalas province-they are only a means to an end. These splits go hand-in-hand with achieving step three, but they also help to make the case that step three is necessary.

Step Three: Establish New Connections. Economic functional regions are characterized by mutually interdependent ties between towns; such ties are currently limited in the area that would become Puncak Andalas province. A major obstacle limiting commerce is Kerinci Seblat National Park. Today there is only one road from the west coast of Sumatra into Kerinci District, which is essentially a large enclave within the park. Two additional roads run north and east out of Kerinci Valley, but other than that there are no other ways around the park, and so it is essentially a massive barrier to commerce and regional integration. The park effectively divides the proposed Puncak Andalas area into four mutually hard-to-access mini regions (see Figure 3). This is a politically contentious issue I have discussed elsewhere, ${ }^{59}$ but district leaders in the areas around the national park resent its existence and see it as an unfair hindrance to economic development for which they receive no compensation. Currently, the fifteen districts surrounding the park have proposed a total of more than thirty road projects through the park. The current roads, along with the park's territory and four of the proposed roads most germane to this discussion, are illustrated in Figure 3. Though these proposed roads cannot yet be considered an inevitability, they are essential for the future of Puncak Andalas province. Moreover, the creation of new districts helps to make the case that these roads are necessary, as I explain in the following paragraphs.

Much of the local rationale for supporting roads is that they will spur economic growth. However, most of the subdistricts around the park are relatively sparsely populated and hence are not very powerful politically, and so they have up until now not been able to muster much support for their road projects. Two small towns are of particular interest in this regard: Lempur, in Kerinci district; and Muara Maderas, in Merangin (see Figure 3).

\footnotetext{
${ }^{57}$ According to numerous local informants in Kerinci district, depending on the office, people are willing to pay as much as IDR150,000,000 (just under US\$16,000) in bribes to secure a position in the district government. This is the equivalent of approximately seven years' salary at the introductory pay grade.

${ }^{58}$ Like many campaign promises, especially those sanctioning illegal activities, this was an oral rather than written promise. After I personally witnessed this bupati candidate tell villagers that he would ensure the formation of a new district if elected, he told me that he had already made arrangements with the Director General of Regional Autonomy at the Ministry of Home Affairs to make the new district a reality.

${ }^{59}$ Keith Bettinger, "Death By 1,000 Cuts: Road Politics at Sumatra's Kerinci Seblat National Park," Conservation and Society (in press).
} 
Figure 3: Connections in Puncak Andalas

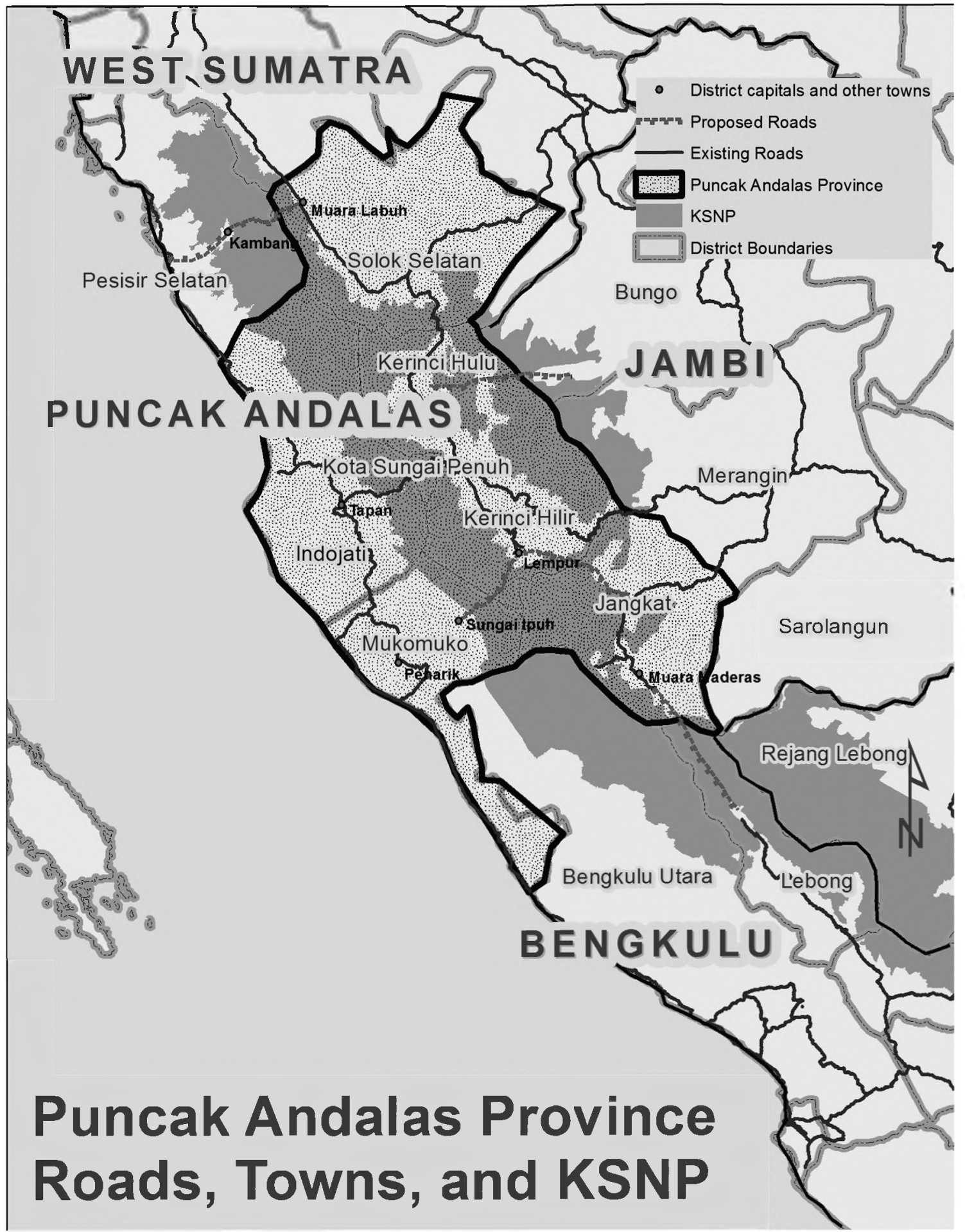

Historically, both of these towns have been rich rice-producing areas, and, because of their relatively isolated locations, they have each developed a distinctive local identity. Now, this isolation is seen as a burden. Both towns are located along roads 
that stop at the edge of Kerinci Seblat National Park, making each of the towns a sort of dead end. Muara Maderas is approximately six hours from Bangko, the district seat of Merangin, while Lempur is approximately two hours from Bukit Tengah, the new seat of Kerinci district. Both towns are also the homes of powerful and vocal minorities in their respective districts. If these two districts succeed in pushing through proposals for district splits, Muara Maderas and Lempur are the most likely choices to become the seats of the two new districts. ${ }^{60}$ Such a development would not only increase the status and prestige of these two towns, but it would also give them a direct line of communication to the provincial governor, as well as more influence in the national parliament, along with greatly enhanced financial resources (in the form of allocations from the central government) to "lobby" for improvements to the districts. In this scenario, it would be far easier for the towns to make a compelling case that additional roads are necessary. In the case of Lempur, two new roads would run through the park. The first of these would go directly to Muara Maderas and Jangkat district, a route that has long been desired by some local residents and bitterly opposed by environmental groups.

The second road would connect Lempur to the small town of Sungai Ipuh and the subdistrict seat of Penarik, in Mukomuko, which would create an easy route from the interior to the coast. Lempur residents have long desired this road as well, and it, too, has been particularly contentious for environmental reasons. This road could potentially spur the exploitation of coal resources in the mountainous interior, as a large coal mining company is currently constructing a modern port facility at the border of Mukomuko and Bengkulu Utara districts. Residents of Lempur also argue that they have historical and cultural ties with both of these areas, and this argument would likely carry more weight if Lempur were a district seat. Muara Maderas would also argue for the road to Lempur and a further connection through the park to Lebong district in Bengkulu province to the south (see Figure 3). These roads have also been proposed.

Two other proposed routes figure prominently in the blueprint for Puncak Andalas Province. Local leaders say the first, a road connecting Kerinci district to Bungo district to the east, would allow for improved market access to more heavily populated areas in Jambi and Riau province, while providing a boost to the tourism industry in Kerinci district. The second road, from Muara Labuh, in Solok Selatan district, to the town of Kambang, in Pesisir Selatan district, would provide another vital link between the high mountain valleys of the Bukit Barisan mountains and the west coast of Sumatra. Road proponents argue that this link would spur inter-district commerce and would also help Solok Selatan develop natural resource-based industries because it would have access to port facilities on the west coast of the island. All together, these new roads would significantly increase access to the region. If approved, the roads together would provide two north-south arteries connected by three east-west roads linking the interior to the coast, providing a strong infrastructural foundation for the new province.

\footnotetext{
${ }^{60}$ The recently elected (2012) headman of Merangin district unseated the incumbent with strong support from Jangkat. His wife is from Muara Maderas, and has over the past year moved aggressively in support of the road project described here.
} 
At the same time, the leadership of Kerinci district (now in partnership with Sungai Penuh) has long worked to develop a regional airport. ${ }^{61}$ Over the past five years, the airport has benefited from significant upgrades, including the hardening and lengthening of its runway and the installation of modern radar equipment. Local leaders have grand ambitions of eventually hosting flights from Malaysia, but they have faced difficulties attracting regular service partners to the airport since flights are frequently cancelled due to weather conditions. Moreover, attracting carriers to service the currently marginal route has required subsidies from the Kerinci district government, which has caused a strain on the budget. However, if Kerinci district is split, the door would be open to some sort of joint-subsidy from the two resulting districts, as the total amount received from the central government would increase significantly. The more immediate goal is to offer regular flights to Jakarta, which local leaders perceive to be a step that would greatly enhance the prestige of the district and would improve Puncak Andalas's chances for approval, since there would be existing linkages between the central government and the prospective provincial capital at Sungai Penuh. ${ }^{62}$

Thus, as can be seen from Figure 3 and the above explanation, these four roads are essential for the development of a coherent functional region. The roads would most likely increase commerce within the larger area, and Sungai Penuh would serve as a natural hub of economic activity, helping to make the case that the region should be elevated to provincial status. And much like steps one and two, it is much easier to develop a base of popular support for roads (at least in this part of Indonesia) than it is for a province. Indeed, in at least three of the districts involved in Puncak Andalas province, some candidates for headman have based their entire political campaigns on promises that they will build roads through the park. New roads, like new districts, enjoy widespread support, which enables local elites to form issue-focused coalitions. At the same time, roads have significant payoffs for local politicians, as they are able directly or indirectly to influence the outcome of the bidding and tendering process for construction contracts. Roads and other infrastructure projects are favorites for district governments throughout Indonesia because they offer such great potential for graft. However, the roads at Kerinci Seblat National Park should be seen in the context of new province formation (and ecological impact, which I consider later). Because these roads are integral to the formation of a functional region, the stakes are much higher.

This discussion describes distinct steps for creating a functional region. However, another noteworthy aspect of this case is the name of the proposed province. All of the provinces established in the post-authoritarian era have names that refer to their geographic extent or location (see Table 1). For example, the name of "BangkaBelitung" province refers clearly to the islands that constitute the new entity. West Papua refers to a specific geographic location. Puncak Andalas, by contrast, does not

\footnotetext{
${ }^{61}$ Depati Parbo Airport; international airport code KRC.

${ }^{62}$ It is also likely that there is a competitive element to the development of the airport. Muara Bungo, the district seat of Bungo district, also has ambitions of forming a new province, which would include Kerinci district. The new province would be called West Jambi, and plans to create it had a significant amount of momentum until early 2012. If the province of West Jambi were, indeed, formed, Muara Bungo would likely become the capital, in which case the Puncak Andalas elite would be left playing second fiddle to a different elite coalition. Muara Bungo has an airport with direct flights to Jakarta, but has so far failed to split itself off from Bungo district to form an administrative municipality.
} 
follow this pattern. Rather, the title refers to a specific topographical feature. Again, this might be dismissed as a trivial curiosity, but, upon contemplation, this curious choice lends support to the arguments presented in this essay. As I argued above, there has never been any unifying political or cultural unit that encompasses all of the constituent areas of Puncak Andalas. In other words, there has never been any formal region here. In fact, the Kerinci area has been described historically as relatively isolated or as a transition area between the Minangkabau-dominated areas to the north and areas under the influence of the Jambi Sultanate to the south. ${ }^{63}$ Moreover, the coastal areas that would be included in the new province consist of a mixture of people as well. Pesisir Selatan and Mukomuko are both Minang rantau areas, but the latter region has also been tied historically to Bengkulu and the Rejang people that inhabit southwest Sumatra. ${ }^{64}$ Therefore, since Puncak Andalas encompasses a variety of people, choosing a geographic name (e.g., Kerinci Province) risks alienating one or more groups, which, given the importance of building popular support for the province, would be counterproductive. Due to the presence of the national park, the name "Kerinci" is also associated with conservation. However, this connotation doesn't support the idea that the area is worthy of having its own province. Puncak Andalas, "the peak of Sumatra," does have the potential to serve as a marker of regional identity. The name is historically rooted, suggesting a long-standing significance. It also has a glorious ring to it, which, intentionally or not, conjures up comparisons to the concept of the mandala, whereby kingdoms in precolonial Indonesia were seen not as bounded political units but rather as centers of power and influence, radiating from the ruler attenuating with geographic distance. ${ }^{65}$ In this conceptualization, Puncak Andalas represents Olympian heights, a symbol of identity visible to the people living on its slopes. Thus, we see that while Puncak Andalas is being pushed as a functional region via a series of administrative and political steps, it also seems that the seed is being planted that the area represents a sort of formal region as well.

\section{What are the Consequences?}

The stakes are indeed high for the regional elites who stand to gain a great deal from the creation of the new province, but all of the negative consequences might be shouldered by local residents if the province does not come to pass. Whether or not the new province is created, there have already been significant changes for residents of these areas (with more to arise upon approval). As Kimura explains:

\footnotetext{
${ }^{63}$ For a variety of accounts of the history of the Kerinci and Serampas areas, see Dominik Bonatz et al., eds., From Distant Tales: Archaeology and Ethnohistory in the Highlands of Sumatra (Newcastle: Cambridge Scholars Press, 2009). Also see the extensive work of Cyril Watson, including "Depati Parbo: A Case Study in Indigenous History," Archipel 15 (1978): 123-43.

${ }^{64}$ See Barbara Watson Andaya, "Cash Cropping and Upstream-Downstream Tensions: The Case of Jambi in the Seventeenth and Eighteenth Centuries," in Southeast Asia in the Early Modern Era: Trade, Power, and Belief, ed. Anthony Reid (Ithaca, NY: Cornell University Press, 1993).

${ }^{65}$ For a discussion of the mandala concept, see Jeyamalar Kathirithamby-Wells, "Socio-Political Structures and the Southeast Asian Ecosystem: Historical Perspectives up to the Mid-Nineteenth Century," in Asian Perceptions of Nature: A Critical Approach, ed. Ole Brunn and Arne Kalland (London: Curzon, 1995), pp. 2547; Damien Kingsbury, The Politics of Indonesia (Oxford: Oxford University Press, 2005); and Benedict Anderson, Language and Power: Exploring Political Cultures in Indonesia (Sheffield: Equinox Publishing, 2006).
} 
... people living in areas with newly drawn local boundaries experience an immediate change in patterns of everyday life. Their leaders suddenly change because new districts or provinces come with new mayors, district chiefs, or governors. Rules change for a range of issues, from tax codes and local budget allocations to public service provision. And the fragmentation affects the physical aspects of everyday life. Where you go to perform even the most mundane tasks, such as registering your car or filing for a marriage license, may suddenly change because of new boundaries. ${ }^{66}$

What Kimura describes is, indeed, true, and in many cases the ease (or difficulty) of obtaining government services depends on where you are. Residents of Kerinci district joke about having to pay the highest bribes to obtain a driving license (the reasoning being that, since civil servants in Kerinci must pay the most compared to other districts to obtain a job, they must charge the highest bribes in order to recoup their investments). As mentioned previously, new districts tend not to fare as well as older, established districts in their efforts to deliver government services efficiently. This is in part due to a lack of skilled personnel in the newer district governments, as district splits tend to dilute the talent pool. ${ }^{67} \mathrm{New}$ officials are also less likely to be familiar with standard operating procedures, best practices, and the regulations associated with their positions. Jacqueline Vel's study of administrative proliferation on the island of Sumba suggests that the rise of new, predatory elites threatens to undermine any positive changes that have arisen from the creation of new districts, ${ }^{68}$ while Tommy Firman describes surveys indicating that most residents of new regions are less satisfied with government performance and service provision in the new region. ${ }^{69}$ Thus, for local residents, administrative proliferation seems likely to lead to a decrease in capacity on the part of their district governments, at least in the short term.

Ironically, one of the main arguments for creating any new province is that local people are neglected by the existing provincial centers in terms of expenditures and service provision. Increasing government service efficiency and enhancing local prestige are also major justifications for supporting district splits, as is witnessed in Kerinci and Pesisir Selatan. The common term for the people's sense of neglect is the same as that used to describe being treated like a step-child, dianak-tirikan. From a geographic perspective, this argument is understandable. All of the districts and potential districts that would be involved in the Puncak Andalas project are among the farthest in their respective provinces from their provincial capitals. However, along the way, in the course of making the case for new districts and provinces, there seems to be a process of almost intentional marginalization. Each step of the way, a certain group or geographic region is systematically marginalized because it is further removed from established centers of power and policy. This may help to make the case that the next

\footnotetext{
${ }^{66}$ Kimura, Political Change and Territoriality in Indonesia, p. 1.

67 "Stocktaking on Indonesia's Recent Decentralization Reforms: Summary of Findings," USAID Report, Jakarta, 2006; BAPPENAS and UNDP, Evaluation of the Proliferation of Administrative Regions in Indonesia, 2001-2007 (Jakarta: Bridge, 2008).

${ }^{68}$ Jacqueline Vel, Uma Politics: An Ethnography of Democratization in West Sumba, Indonesia, 1986-2006 (Leiden: Koninklijk Instituut Voor Taal- Land- en Volkenkunde, 2009).

${ }^{69}$ Firman, "Territorial Splits in Decentralizing Indonesia."
} 
round of administrative proliferation is needed, but it is not sufficient in terms of the law, and certainly there is a limit to how many times regions can be split. Thus, if Puncak Andalas province does not materialize but the constituent districts do, the residents of the new districts may find themselves even more marginalized and shut out by established elites and informal networks of political patronage in the existing provincial capitals.

Consider the case of the five subdistricts in Merangin district that would be split off to form Jangkat district. These subdistricts are already remote, far from not only the provincial capital at Jambi City but also the district seat at Bangko. In addition to their isolation (or perhaps because of it), these subdistricts are among the poorest in Merangin in terms of standard of living and among the least likely to be reached by government services. ${ }^{70}$ Splitting these subdistricts off from Merangin would concentrate administratively a group of people who are relatively poor and relatively less served by the government, and separate them even further from an established government that is better equipped to address the aforementioned problems than the new district government would be. There is also the possibility that, once the mother district is aware of a desire on the part of several subdistricts to break away, those subdistricts will receive less attention (and thus fewer funds) from the district government. The same could be said for districts attempting to break away from existing provinces to form new provinces; knowledge of the plans could lead the provincial government to reconsider spending in the districts planning to bolt. Moreover, if the formation of the new province fails, there may be lasting effects in terms of the influence of assembly members from the breakaway districts, and the relations between the province and the districts may suffer in other ways.

Lastly, a word on the consequences for Kerinci Seblat National Park. Robin Burgess and others recently used MODIS (Moderate Resolution Imaging Spectroradiometer) satellite imagery for the years spanning 2000-08 to analyze the effects of new district formation on deforestation rates in Indonesia. ${ }^{71}$ They concluded that there is an increase in deforestation where new districts are created. In new districts where a national park was present, there was still an increase in deforestation, but it was less than the increase in non-national park forests. Kerinci Seblat National Park is currently experiencing significant problems with deforestation stemming from agricultural encroachment within the park. These problems are worse in newly created districts. ${ }^{72}$ Moreover, many of the district governments around the park are antagonistic towards the park (e.g., because of restrictions on economic development), and in some cases district leaders take "behind the scenes" steps to undermine the park's borders. ${ }^{73}$ It

\footnotetext{
${ }^{70}$ This statement is based partially on observation and interviews, but also on an interpretation of district statistics. While most districts in Indonesia do not calculate per capita income for each subdistrict, they do record annual numbers of Hajj pilgrims and percentages of residents with government registration cards (Kartu Tanda Penduduk, KTP). I used these numbers as proxies for household income and effectiveness of government service delivery; based on these criteria, the Jangkat subdistricts were among the lowest in the district. The same holds true for Mukomuko district when compared to the rest of Bengkulu province and the three (now six) southernmost subdistricts of Pesisir Selatan.

${ }^{71}$ Robin Burgess, Benjamin Olken, Matthew Hansen, Peter Potapov, and Stefanie Sieber, The Political Economy of Deforestation in the Tropics (Cambridge, MA: National Bureau of Economic Research, 2011).

${ }^{72}$ This statement is based on my as-of-yet unpublished doctoral dissertation fieldwork.

${ }^{73}$ Bettinger, "Death by 1,000 Cuts."
} 
stands to reason that the creation of new districts and a new province will increase direct and indirect pressures on the park. Moreover, agriculture is the predominant economic activity in all of the Puncak Andalas districts. Economic development on Sumatra relies on commodity extraction and primary sector activity, including mining and the extensification of plantation crops, such as oil palm. New districts seek to increase locally generated revenues by encouraging these types of economic activities. However, all of the Puncak Andalas districts have significant percentages of their territory sequestered within the park, and so economic options are limited. Newdistrict proponents seem to ignore the limitations imposed on them by the park, however. For example, the chairman of the committee to support Ranah Indojati district recently remarked that new coal mining operations and oil palm plantations would help the proposed district generate operating funds, but, given that at least 50 percent of the proposed district is covered by the park, and given current land uses within the district, it is difficult to imagine where the mines and plantations will be located if not in the park. Moreover, the roads that have been shown to be integral to the new province's fate have been bitterly opposed by local, national, and international conservationists because of, among other concerns, the impact they would have on animal habitat, such as that of the critically endangered Sumatran tiger. These conservationists also argue that the new roads would facilitate even more poaching, illegal logging, and encroachment, which is consistent with experiences elsewhere on

Sumatra. In addition to these direct impacts, elevation to provincial status would likely give political elites in the area and their clients more influence at the national level. This would likely be manifested in calls to degazette parts of the park, as statements to this effect are frequently heard from district leaders in the areas around the park. Indeed, removing formal protections from all or parts of KSNP might become the central preoccupation of leaders of the new province.

Thus, the negative consequences will almost certainly not be felt by those pushing most adamantly for the new province, but rather by the residents of the districts as well as the ecosystems that support the agricultural activities on this part of Sumatra. Scarce government resources that might be better allocated towards improving government service delivery in underserved areas have, in many cases, been diverted to the several sub-goals related to the formation of the new province.

\section{Conclusions}

Since Indonesia declared independence from the Dutch in 1945, the country's internal borders have been periodically shifted and redrawn, and new provinces, districts, and administrative municipalities have been created. During the Guided Democracy and New Order periods, most instances of new-region creation were initiated or at least coordinated from Jakarta and figured, directly or indirectly, into an overall strategy of centralization and control. For example, the formation of Riau and Jambi provinces from Central Sumatra in 1957 can be seen as part of the central government's response to the emergence of the PRRI (Pemerintah Revolusioner Republik Indonesia, Revolutionary Government of the Republic of Indonesia) movement on Sumatra. Booth refers to this split and others carried out in the 1950 s as 
part of a "'divide and rule' tactic implemented by a central government facing armed insurrections in several regions and the threat of more violent outbreaks in others. ${ }^{74}$ Thus, it can be argued that administrative proliferation prior to 1998 was a centrally directed and driven process. However, since the fall of Suharto, Indonesia has experienced unprecedented administrative proliferation. Decentralization has provided opportunities for locally and regionally anchored elites to pursue new districts and provinces, and so the process of administrative proliferation has become much more decentralized and, in many cases, new provinces are the result of regional movements and coalitions.

A major contribution of this essay is that it sheds light on a type of territorial coalition that has hitherto been unexamined in the empirical and theoretical literature on province formation: elite coalitions that cross provincial boundaries with the goal of cobbling together parts of existing administrative units to construct a regional identity in order to create a new province. This sort of collaboration is of particular interest now that the moratorium on the creation of new regions is no longer in effect. It is reasonable to expect a flurry of new proposals, and it is likely that locally anchored coalitions will become increasingly creative in their efforts to build support and justification for new provinces. This includes coalitions that cross district and provincial lines. One clear example of this is the recent, increasingly loud call to create a new province from pieces of East Kalimantan and South Kalimantan provinces. This new province would be called Southeast Kalimantan, and the campaign to establish it has been driven by claims that the current provincial leadership has long neglected the peripheral areas in question. ${ }^{75}$ There have also been calls for a new province to be formed from pieces of Bengkulu and South Sumatra provinces.

Each of these gestating territorial coalitions represents a locally anchored challenge to the existing administrative geography of Indonesia. They also demonstrate the fundamental differences in visions of administrative proliferation between Jakarta and the regions. As the central government, through the Ministry of Home Affairs and its Grand Design for Regional Arrangement, attempts to impose order and control the process of administrative proliferation, regionally rooted blocks attempt to cultivate alliances and will continue to exploit regional autonomy laws. These laws inadvertently create a series of steps for the creation of "kingdoms of authority," allowing local elites gradually to increase their power and influence by using the powers and policy tools at their disposal. Each step opens up new possibilities and allows for the emergence of powerful coalitions that bring together geographically dispersed territorial aspirations. The case of Puncak Andalas shows how this new province could be a vehicle not just for those who are currently in power in relatively remote corners of three provinces, but also for aspiring elites who have until now been unable to gain access to the levers of state power. I have shown how Puncak Andalas appeals to actors at several scales, from leaders of isolated villages all the way up to provincial legislators and governors. This case supports Kimura's assertion that the formation of new provinces is not a zero-sum game producing absolute winners and loser. Rather, actors at various scales in both the new province and those ceding land

\footnotetext{
${ }^{74}$ Booth, "Splitting, Splitting, and Splitting Again," p. 36.

${ }_{5}$ Tunggadewa Mattangkilang, "East Kalimantan Officials Seek New Provinces," Jakarta Globe, April 6, 2013, p. 10.
} 
for the new province stand to benefit a great deal from the establishment of Puncak Andalas.

The campaign to create Puncak Andalas may ultimately fail. However, the case demonstrates ongoing contestation over how administrative regions will be defined in an increasingly decentralized Indonesia. It also demonstrates how the central preoccupation of many regional elites in the post-authoritarian era is not on improving governance and delivering government services to Indonesia's citizens, but rather on increasing their own prestige and rent-seeking opportunities. 